\title{
CHANGES IN THE LEVEL OF MOTOR PREPARATION OF PROFESSIONAL SOCCER PLAYERS IN TRAINING
}

\author{
MATEUSZ KOZIEŁ, JAKUB GRZEGORZ ADAMCZYK \\ Józef Pitsudski University of Physical Education in Warsaw, Faculty of Physical Education, \\ Chair of Sport, Warsaw, Poland
}

\begin{abstract}
Mailing address: Jakub Grzegorz Adamczyk, Józef Piłsudski University of Physical Education in Warsaw, Faculty of Physical Education, 34 Marymoncka Street, 00-968 Warszawa, tel.: +48 22 8347663, fax: +48 22 8651080, e-mail: jakub.adamczyk@awf.edu.pl
\end{abstract}

\begin{abstract}
Introduction. Since the competition period has been prolonged in modern football, it is important to know if a shortened preparatory phase is enough to improve motor fitness preparation. This study analysed the changes in the level of physical fitness in second-league soccer players with respect to training conducted during the preparatory period. Material and methods. Speed (5-m and 30-m sprint), endurance (progressive test), and power (Counter Movement Jump) were tested in 21 players at the beginning and at the end of the preparatory phase. Results. The results obtained indicate a significant improvement in physical capacity parameters as well as speed and strength abilities measured using $5-\mathrm{m}$ and $30-\mathrm{m}$ running speed tests and the CMJ test for muscle power. In the progressive test measuring anaerobic threshold speed, the players active in the central section of the pitch (centre-backs and central midfielders) achieved the best results, while in the speed trials and explosive strength trials, side-backs and side midfielders achieved the best results. Conclusions. During the winter preparatory season, the most significant changes in the physical fitness of soccer players were observed in aerobic endurance expressed as threshold speed (an increase of $1.2 \mathrm{~km} / \mathrm{h}$ ) and running speed measured as the time needed to cover a distance of $5 \mathrm{~m}$ (time reduced by $0.04 \mathrm{~s}$ ) and $30 \mathrm{~m}$ (time reduced by $0.07 \mathrm{~s}$ ). These traits are crucial in the preparation of soccer players for league matches and have the greatest impact on their performance in sports competitions.
\end{abstract}

Key words: football, physical fitness, preparatory phase, motor preparation

\section{Introduction}

A player's physical fitness is reflected in their activity on the football pitch and is characterised by a combination of movements including stops, decelerations, accelerations, sudden direction changes, jumps, and activities strictly related to the football technique [1]. Mohra et al. reported that during the Champions League and Italian Serie A, players needed to make use of their physical fitness to perform more than 1,300 such movements [2]. The player's effort depends on a number of variables, such as the position on the pitch, the pace of the game, the opponent, or the level at which the player competes.

However, the key element of the physical fitness of players is the level of basic motor characteristics such as speed or stamina. Aerobic endurance is a basis for building a player's stable physical condition, and it also extends the time of playing in psychological and motor comfort, which helps to maintain an adequate level of technical-tactical activities and further increases the efficiency of speed training [4].

Another speed-related element is the maximum run velocity of the player as, even if the player is able to perform more sprints during a game, it is the speed that ultimately decides whether direct one-on-one confrontations with the opponent are won [5]. The positive influence of strength training in injury reduction has also been documented on multiple occasions, as demonstrated by a meta-analysis conducted by Lauersen et al., where the muscle strength training was associated with a $1 / 3$ reduction in players' vulnerability to injuries [6].
The increased training, regeneration, and nutrition requirements as well as the time deficit during pre-season preparation has encouraged a search for the optimisation of the training and attempts to synthesise the development of motorics with technical-tactical elements. Current trends indicate that the new principles of team preparation in modern football include a high level of aerobic endurance, which constitutes a basis for further improvement of physical fitness, as well as an appropriate transitional period in order to minimise the overtraining syndrome [7].

Considering the prolonged competitive period, it is reasonable to pose the question whether, with a significantly shortened preparatory period in football, it is possible to achieve considerable changes in training level. Therefore, the purpose of the study was to observe the changes in the fitness level of 2nd division footballers during a winter preparatory period as a function of their position on the pitch.

\section{Material and methods}

Twenty-one players training football at RKS Radomiak Radom, a Polish 2nd division club, participated in the study. The characteristics of the group, taking into account the field sectors occupied (central sector players, side sector players, and strikers) are presented in Table 1. 
Table 1. Biometrical characteristics of RKS Radomiak Radom players divided according to pitch position

\begin{tabular}{|c|c|c|c|c|c|}
\hline & $\begin{array}{l}\text { Body } \\
\text { height } \\
\text { [m] }\end{array}$ & $\begin{array}{c}\text { Body } \\
\text { mass } \\
{[\mathrm{kg}]}\end{array}$ & BMI & $\begin{array}{c}\text { Age } \\
\text { [years] }\end{array}$ & $\begin{array}{c}\text { Training } \\
\text { experience } \\
\text { [years] }\end{array}$ \\
\hline $\begin{array}{l}\text { Side sector } \\
\text { players }\end{array}$ & $\begin{array}{c}1.77 \\
\pm 0.07\end{array}$ & $\begin{array}{l}71.75 \\
\pm 6.54\end{array}$ & $\begin{array}{l}22.95 \\
\pm 1.39\end{array}$ & $\begin{array}{l}24.88 \\
\pm 3.91\end{array}$ & $\begin{array}{c}8.00 \\
\pm 3.82\end{array}$ \\
\hline $\begin{array}{c}\text { Central sector } \\
\text { players }\end{array}$ & $\begin{array}{c}1.85 \\
\pm 0.06\end{array}$ & $\begin{array}{l}80.89 \\
\pm 8.21\end{array}$ & $\begin{array}{l}23.55 \\
\pm 1.34\end{array}$ & $\begin{array}{l}24.38 \\
\pm 2.83\end{array}$ & $\begin{array}{c}7.50 \\
\pm 2.62\end{array}$ \\
\hline Strikers & $\begin{array}{c}1.83 \\
\pm 0.07\end{array}$ & $\begin{array}{l}77.73 \\
\pm 7.95\end{array}$ & $\begin{array}{l}23.30 \\
\pm 0.73\end{array}$ & $\begin{array}{l}24.00 \\
\pm 4.62\end{array}$ & $\begin{array}{c}7.00 \\
\pm 4.62\end{array}$ \\
\hline Whole team & $\begin{array}{c}1.81 \\
\pm 0.07\end{array}$ & $\begin{array}{l}76.38 \\
\pm 8.13\end{array}$ & $\begin{array}{l}23.21 \\
\pm 1.23\end{array}$ & $\begin{array}{l}24.76 \\
\pm 3.59\end{array}$ & $\begin{array}{c}7.86 \\
\pm 3.50\end{array}$ \\
\hline
\end{tabular}

A physical fitness test was conducted after the end of the autumn 2015/2016 season (progressive test) and at the beginning of the winter preparatory period for the spring round of the Polish 2nd Division in the 2015/2016 season (speed and power). Additional tests were conducted after the completion of the first mesocycle of the preparatory period to measure muscle strength and aerobic endurance (progressive strength test and body composition) and after the completion of the second mesocycle in order to measure changes in speed and power. The characteristics of the training loads implemented during the preparatory period are presented in Table 2 . The players were tested under the supervision of the club doctor.

The speed assessment was based on a 30-m run with a lap time of 5 minutes, because it takes into account the specificity of the exercise performed during the match, in which players run short distances on the pitch at maximum speed (the average sprint length is $17 \mathrm{~m}$ ) [8]. Microgate Witty photocells were used to measure the time, and the test was performed on an athletic field with a tartan surface to compensate for the effects of weather conditions (wind, temperature, and rain) on the results. The test was conducted three times, and the best time out of the three trials was used in the analysis. The result was calculated with accuracy to $0.01 \mathrm{~s}$.

The players' speed capacity was developed by building their muscle strength, which is closely related to the results achieved during the sprint in the first mesocycle of the preparatory phase [9]. Additional exercises aimed at improving the speed of movement consisted of activities that enhance running technique, both in the static form (maintaining the correct alignment of individual body segments in the crosscountry position) and dynamic form (e.g., marching on elastic harnesses). In the second mesocycle, there was a direct focus on performing sprints using the repetition method, where repeated exercises were performed at maximum speed for further improvement.

Another factor examined was power/explosive force. For this purpose, a Counter Movement Jump test with arm swing was conducted [10]. The test was performed in an athletic hall with the use of the Microgate OptoJump system [11]. The parameter that was subjected to quantitative analysis was the height of the jump of the player. The measurement was performed twice; the best result was recorded for analysis, and the test was preceded by a demonstration of the correct performance of the exercise [12, 13].

Muscular power, as in the case of speed, was shaped by the development of the muscle strength of the players participating in the study in the first mesocycle of the preparatory period. This kind of training was based on an understanding of the physical

Table 2. RKS Radomiak Radom training loads in the preparatory period (each training had more than one focus)

\begin{tabular}{|c|c|c|}
\hline Focus & Number of training sessions & Training contents \\
\hline $\begin{array}{l}\text { 1st mesocycle: strength and aerobic } \\
\text { endurance } \\
\text { 2nd mesocycle: explosive strength } \\
\text { (power) and speed }\end{array}$ & $\begin{array}{l}\text { Total number of training sessions } \\
\text { and total time of workouts: } 70 \text {; } \\
97 \text { h } 50 \text { min. }\end{array}$ & - \\
\hline Strength & 12 & $\begin{array}{l}\text { Load progression: } 40 \rightarrow 85 \% \text { of } 1-\mathrm{RM} \\
\text { Regression of repetitions: } 15 \rightarrow 3-5 \\
\text { Number of sets: } 3 \rightarrow 5\end{array}$ \\
\hline Power & 9 & $\begin{array}{l}\text { Full squat, Second pull, Jerk, Swing with kettle bell, 10-m run with elastic resist- } \\
\text { ance, Jumps with barbell, Medicine ball throws. }\end{array}$ \\
\hline Endurance & 23 & $\begin{array}{l}11 \text { interval trainings ( } 318 \mathrm{~min}) \text { based on maximal aerobic epeed, } 12 \text { trainings with } \\
\text { Verheijen methods ( } 539 \mathrm{~min}) \text {. }\end{array}$ \\
\hline Technical and tactical preparation & 49 & $\begin{array}{l}\text { Preparatory period was focused on improving behaviour in all phases of the game } \\
\text { in 1-4-2-3-1 and 1-4-4-2 systems, according to the rules adopted in the team's } \\
\text { game model. }\end{array}$ \\
\hline Speed & $\begin{array}{l}26 \text { sets (including strength and power } \\
\text { in preparatory period) and } 9 \text { sets } \\
\text { (strictly for speed) }\end{array}$ & $\begin{array}{l}\text { These } 9 \text { sets included: } \\
\text { - } 4 \text { sets of teaching proper running technique, totalling } 65 \text { min, } \\
\text { - } 1 \text { set of first phase of plyometric exercise, } \\
\text { - } 4 \text { sets of isolated sprints, totalling } 695 \mathrm{~m} \text {. } \\
\\
\text { Besides strength and power training, which was an integral part of speed workouts, } \\
\text { in each training session, drills were chosen in order to include short explosive } \\
\text { efforts along with reaction to visual stimuli. Moreover, during tactical drills, close } \\
\text { attention was paid to quick action after losing or receiving the ball. }\end{array}$ \\
\hline
\end{tabular}


dependence where each player's movement requires appropriate force and speed, and their combination creates power. During the second period of work on muscle strength, the focus was on aerobic exercises (jumps) and on dynamic strength exercises such as jumping with a barbell held on the back of the shoulders or pressing the barbell from the chest to above the head, where the main focus was on training at maximum speed rather than on the external load.

The strength of the players was determined by an invasive progressive test that allowed the thresholds (aerobic and anaerobic thresholds) to be determined. This test consisted of a two-minute back and forth run over the distance of $20 \mathrm{~m}$ (commencing with a sound signal), after which the laboratory performed a blood test to determine lactate concentration in capillary blood using a Lactate Scout device $[15,16]$. The passive rest interval between different stages of the test was 30 seconds, and this was caused by the need to measure the lactate concentration in the capillary blood of the player tested. The player's heart rate was monitored throughout the duration of the exercise using a Polar Team 2 Pro system [17]. The speed at which each stage was covered is shown in Table 3. The test continued until volitional exhaustion, and the result was the number of the stage at which the test ended as well as the total duration of the test.

The endurance of the players was developed in two different ways. The first one was isolated work in the form of running based on the Maximal Aerobic Speed (MAS) parameter, which was determined before the commencement of the transition period in a five-minute run test [18]. The other method of working on improving endurance levels, with reference to the specificity of the discipline, was various games $(4 \times 4,6 \times 6$, and $11 \times 11)$ based on the Verheijen methodology of football training.

Table 3. Velocity of 20-m swing run in consecutive stages of the test

\begin{tabular}{|c|c|c|}
\hline Stage & Run velocity & Time for $20 \mathrm{~m}$ \\
\hline 1 & $8 \mathrm{~km} / \mathrm{h}$ & $9 \mathrm{~s}$ \\
\hline 2 & $10 \mathrm{~km} / \mathrm{h}$ & $7.2 \mathrm{~s}$ \\
\hline 3 & $11.5 \mathrm{~km} / \mathrm{h}$ & $6.26 \mathrm{~s}$ \\
\hline 4 & $12.5 \mathrm{~km} / \mathrm{h}$ & $5.76 \mathrm{~s}$ \\
\hline 5 & $13.5 \mathrm{~km} / \mathrm{h}$ & $5.33 \mathrm{~s}$ \\
\hline 6 & $14.5 \mathrm{~km} / \mathrm{h}$ & $4.97 \mathrm{~s}$ \\
\hline 7 & $16 \mathrm{~km} / \mathrm{h}$ & $4.50 \mathrm{~s}$ \\
\hline
\end{tabular}

The results obtained were analysed statistically. They were presented using descriptive statistics. Normality of distribution was determined using the Kolmogorov-Smirnov test. The variation between the positions on the pitch and the changes in the results during the preparatory period were determined by means of Student's t-test for dependent variables. The correlation between the selected training parameters was determined with the use of Pearson's correlation coefficient. Statistical significance was set at $\mathrm{p} \leq 0.05$.

\section{Results}

The results showed statistically significant differences in the level of endurance preparation in central sector players $(\mathrm{p}<0.001)$ and among strikers and players in the side sector $(\mathrm{p}=0.01)$.

Despite similar baseline levels (Fig. 1) of anaerobic threshold speed among all players after the winter preparatory period, the central sector players achieved the highest improvement, increasing it by $1.8 \mathrm{~km} / \mathrm{h}$ on average. Attackers had merely half of this increase $(0.9 \mathrm{~km} / \mathrm{h})$, and the players in the farthest parts of the pitch had a three times lower improvement $(0.6 \mathrm{~km} / \mathrm{h})$.

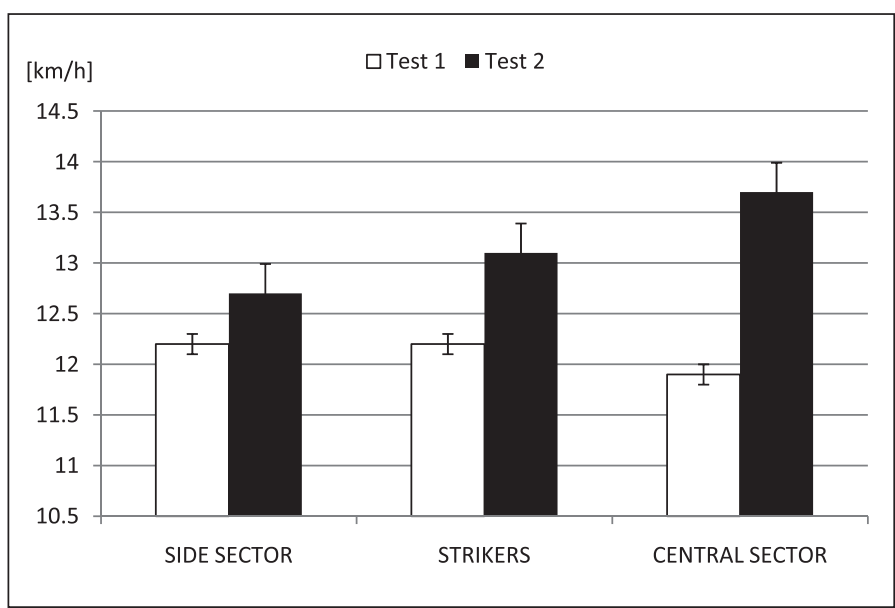

Figure 1. Mean values of changes in anaerobic threshold speed during winter preparatory period

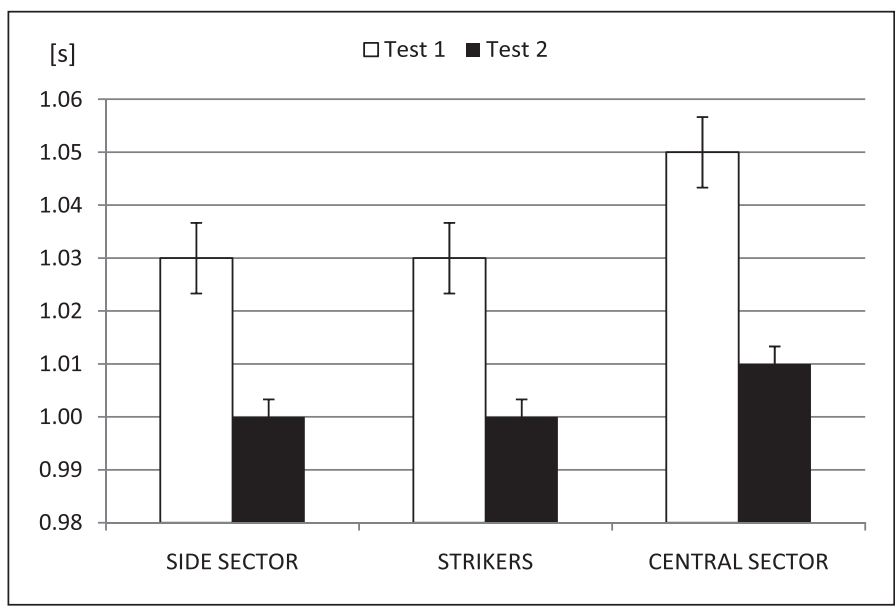

Figure 2. Mean values of changes in maximal speed at $5 \mathrm{~m}$ during winter preparatory period

The running speed test at 5 metres did not show any significant differences between the players in the different sectors of the field. The changes observed were almost identical in all study groups and amounted to 0.03-0.04 s (Fig. 2).

Players operating closer to the pitch side lines had the best results in the speed test at $30 \mathrm{~m}(4.03 \mathrm{~s})$, while the weakest scores were recorded for the players who concentrated their game in the central sector (4.11 s), as shown in Figure 3.

The positive changes recorded for particular groups and the improvement of the results for 18 out of 21 players involved in the test meant that the differences between baseline levels at $30 \mathrm{~m}$ and those obtained after training were statistically significant $(p=0.0002)$. When the players were divided according to their position on the pitch, significant changes in the speed at $30 \mathrm{~m}$ were only found among central sector players $(\mathrm{p}=0.02)$. In the other groups, the differences observed were not statistically significant $(\mathrm{p}>0.05)$. 


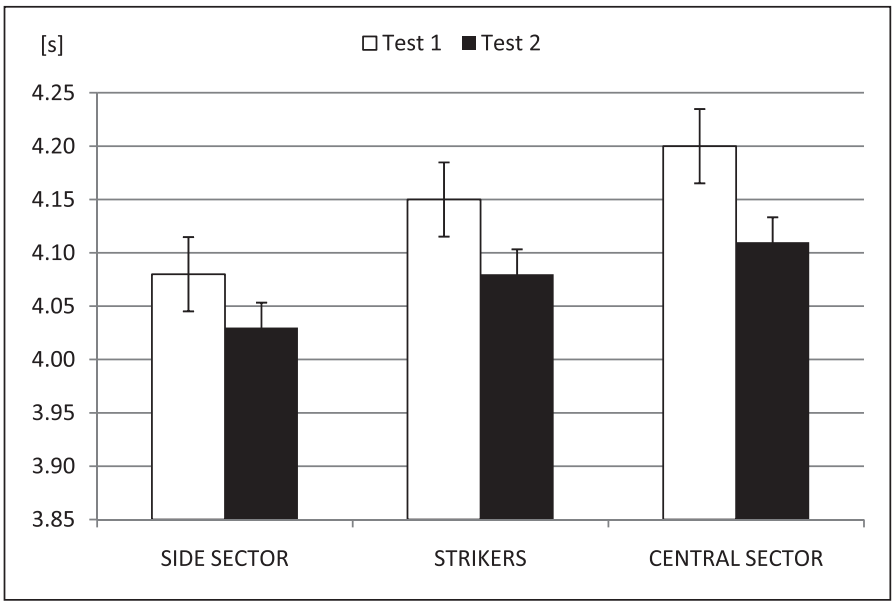

Figure 3. Mean values of changes in maximal speed at $30 \mathrm{~m}$ during winter preparatory period

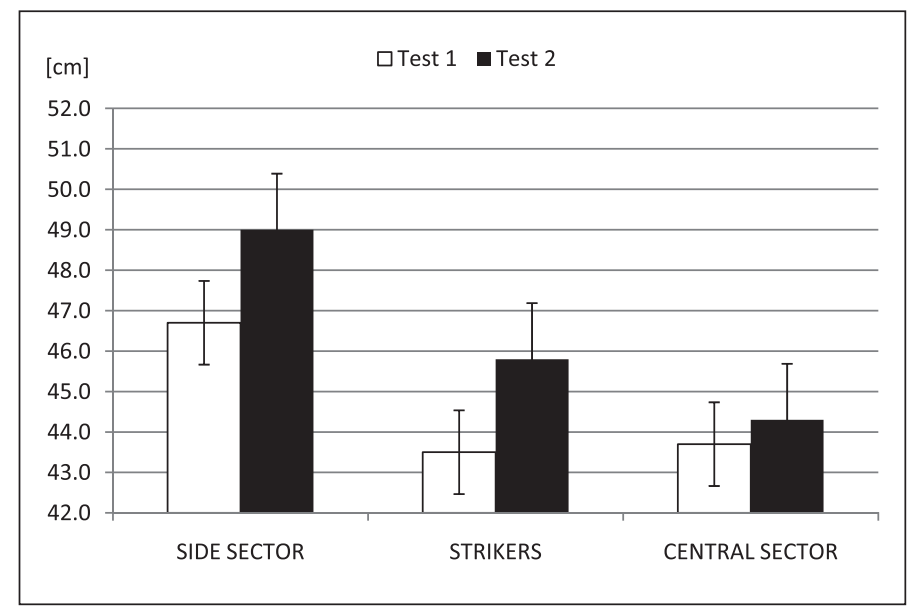

Figure 4. Mean values of changes of power in Counter Movement Jump (CMJ) test during winter preparatory period

The results obtained for the team studied are presented in Figure 4. They indicate a higher level for side sector players in the CMJ test with arm swing, in comparison to the other players. The initial level of the feature tested among the players operating on the field side lines was on average over $6 \%$ higher $(3.0-3.2 \mathrm{~cm})$. During the trials performed later, this difference increased with respect to the middle defenders and central midfielders to over $9 \%(4.7 \mathrm{~cm})$, but no changes were recorded with respect to strikers.

The changes in muscle power level achieved in the CMJ test were statistically significant for the entire Radom team $(p=0.02)$ and for side sector players only $(p=0.03)$ when the players were divided into groups according to their position on pitch.

Further statistical tests showed that there was a strong correlation between 30-m sprint speed and the muscle power level achieved in the CMJ trials $(\mathrm{r}=-0.69, \mathrm{p}<0.05)$. No such correlation was detected with regard to running at a distance of 5 metres and CMJ ( $p>0.05)$. No other correlations between the levels of individual motor characteristics after the preparatory period were found $(\mathrm{p}>0.05)$.

\section{Discussion}

\section{General characteristics of preparatory period}

During the preparatory period of over eight weeks of work, the players performed more than 70 training units, which, in quantitative terms, is similar to the training of top-league teams [20].

The results of the research indicate significant changes in the level of particular motor features among the football players during the winter preparatory period. Each of the players progressed in at least two out of three motor characteristics analysed (endurance, speed, and muscle power), which may be seen as evidence that the players were well physically prepared for the competition phase [1].

\section{Endurance}

Threshold speed has been studied by many authors internationally but also by Polish authors, who used the Jastrzębski test, mainly to determine heart rate and speed. In the research of the latter, the Polish Football Premier League teams of Górnik Łęczna and Zagłębie Lubin achieved an average speed of $13.2 \mathrm{~km} / \mathrm{h}$ and $13.5 \mathrm{~km} / \mathrm{h}$, which is similar to the results of the group of Radomiak football players $(13.2 \mathrm{~km} / \mathrm{h})$ [20]. In the past, Śledziewski reported lower values for the Polish Football Premier League than those in the group studied, and the average threshold speed in his study was $13.0 \mathrm{~km} / \mathrm{h}$ [21]. A noticeably higher baseline level $(13.6 \mathrm{~km} / \mathrm{h})$ and significant improvement $(14.4 \mathrm{~km} / \mathrm{h})$ was observed among 19 juniors on the KKS Lech Poznań S.A. team [22], which is significantly better than the results of the Radomiak players. Similar results were obtained by McMillan in a study of a nine-person team of 18 -year-old footballers who had an average speed of $13.6 \mathrm{~km} / \mathrm{h}$ before the start of the preparatory period and $14.7 \mathrm{~km} / \mathrm{h}$ after this period. In this case, the only similarity is the achievement of almost identical progress of the team from Radom $(1.2 \mathrm{~km} / \mathrm{h})$ and British footballers $(1.1 \mathrm{~km} / \mathrm{h})$ [23]. Even greater improvements were achieved by Brazilian players who, after completing a 12 -week training cycle, raised the threshold speed from $13.3 \mathrm{~km} / \mathrm{h}$ to $14.8 \mathrm{~km} / \mathrm{h}$. Turkish researchers investigated the relationship between the threshold speed and the position on the pitch. They tried to determine the physical profiles of the players in different formations and discovered that the highest level of attack speed was achieved by strikers $(14.0 \mathrm{~km} / \mathrm{h})$, followed by defenders $(13.7 \mathrm{~km} / \mathrm{h})$, and the weakest results were achieved by midfielders $(13.3 \mathrm{~km} / \mathrm{h})$ [25]. Comparing the above to the results obtained in this research, the Radomiak strikers had a significantly lower threshold speed $(13.1 \mathrm{~km} / \mathrm{h})$, while central sector players achieved the same value as the defenders from Turkey $(13.7 \mathrm{~km} / \mathrm{h})$ and were better than the strikers as well as the side sector players $(12.7 \mathrm{~km} / \mathrm{h})$ in our study.

Many studies indicate the benefits of isolated endurance training [26], but some authors used football-specific training measures of equal intensity and achieved equally satisfactory progress, for example through the use of small-sided games [27].

\section{Maximum speed achieved at 5-m distance}

Research conducted on Brazilian footballers showed that $96 \%$ of sprints during a football match take place at distances under 30 metres, while only about half (49\%) are under 10 metres [28]. In light of the above results, the acceleration achieved in the first few steps becomes even more significant in its effect on individual and team performance [29].

When analysing the progress achieved by the Radomiak players in a speed test of 5 metres (Fig. 2), it can be noticed that 
the players, regardless of their position on the pitch, achieved results that were better by $0.03-0.04 \mathrm{~s}$ after the preparatory period, which further made the level of the team more homogenous. There were no significant differences between the groups at 5 metres, and the results were consistent with those of 289 Belgian footballers, with the strikers being the best, followed by the side defenders and the midfielders, and with the midfield defenders being the poorest [30].

It is also worth examining the results of tests conducted on Spanish referees. The results of 41 referees showed that the average time needed to cover a five-metre distance was $0.97 \mathrm{sec}-$ onds, which is 0.03 seconds better than was found from the players from Radom [31]. Surprisingly, they were also faster than professional footballers who, in the study conducted by Styles et al., achieved an improvement of $1.11 \mathrm{~s}$ before the training and up to $1.05 \mathrm{~s}$ after the training [32].

\section{Speed achieved at 30-m distance}

In a study of professional Hong Kong football players, it was found that a 30-metre run could be improved with 8 weeks of strength training (an improvement from $4.41 \mathrm{~s}$ to $4.29 \mathrm{~s}$ was achieved), but no benefits were found after a heavy interval training programme [33]. Eccentric exercises and the use of vibration had no influence on movement speed, as documented by other authors, studying Spanish players under the age of 18 [34].

A comparison of the players from Radom to the professional players of European leagues is favourable for the Radom players and partly confirms also that the highest speed $(7.14 \mathrm{~m} / \mathrm{s})$ is achieved by the midfielders and strikers $(7.10 \mathrm{~m} / \mathrm{s})$, followed by the players of the side sectors of the field $(6.99 \mathrm{~m} / \mathrm{s})$ and central defenders $(6.82 \mathrm{~m} / \mathrm{s})[20,35,36]$.

It is also worth mentioning that speed abilities are strongly correlated with the strength and power of the legs [37], which was also confirmed by our tests.

\section{Power}

In football, the muscle power level is also considered one of the most important parameters, because its use is visible in both the defence phase (e.g., ball reception, body play) as well as in the attacking phase (e.g., ball strike) [38].

Changes in the level of power during the preparatory period among the Radom players were negligible, and similar observations were noted during the preparation period in Brazilian players [39]. The results of both studies may indicate that there is little chance of developing muscle power in the preparation of a football team for league competitions. More emphasis is put on endurance and speed training, so muscle power growth may be a result of other changes, as evidenced by the correlation discovered.

Within the team division studied, the greatest improvement was achieved by strikers, while the least progress was observed for central field players, and therefore the findings of the study by Boone et al. [30], where midfield defenders were the best in both tests, were not confirmed. The analysis of subsequent studies shows that the average muscle strength of the players in both tests is significantly higher than the strength of the Belgian [40], French [36], and Estonian [41] players examined by other authors.

\section{Conclusions}

1. During the winter preparatory period, the most significant changes in the physical fitness of football players were observed at the aerobic level, as determined using anaerobic threshold speed $(1.2 \mathrm{~km} / \mathrm{h})$ and running speed measured by the time necessary to cover a 5-m distance (reduction in time of $0.04 \mathrm{~s}$ ) and 30-m distance (reduction in time of $0.07 \mathrm{~s}$ ). These are the key features in the preparation of players for league games and have the greatest impact on the level of competition in the sport.

2. Research has shown that the motor characteristics that are dominant at different positions are as follows.

- The dominant feature of middle sector players was endurance.

- The dominant feature of side sector players was speed of movement and muscle power.

- The strikers were second in terms of their performance, which may be seen as evidence of the versatility of the players, which is necessary in order to gain advantage in many different ways both against the opponent's defenders and goal-keeper.

\section{Literature}

1. Bompa T., Haff G. (2009). Periodization - 5th Edition. Theory and methodology of training. Champaign: Human Kinetics.

2. Mohr M., Krustrup P., Bangsbo J. (2003). Match performance of high-standard soccer players with special reference to development of fatigue. Journal of Sports Sciences 21, 519528.

3. Ingebrigsten J., Bendiksen M., Randers M.B., Castagna C., Krustrup P., Holtermann A. (2012). Yo-Yo IR2 testing of elite and sub-elite soccer players: Performance, heart rate response and correlations to other interval tests. Journal of Sport Sciences 30(13), 1337-1345.

4. Chmura J. (2014). Warm-up. Physiological basis and practical applications. Warszawa: PZWL. [in Polish]

5. Chmura J., Duk O., Min K., Kawczyński A., Chmura P., Mroczek D. (2011). Endurance and speed capacity of the Korea Republic football national team during the World Cup of 2010. Journal of Human Kinetics 30, 115-121.

6. Lauersen J.B., Bertelsen D.M., Andersen L.B. (2014). The effectiveness of exercise interventions to prevent sports injuries: A systematic review and meta-analysis of randomized controlled trials. British Journal of Sports Medicine 48(11), 871-877.

7. van Winckel J., Helsen W., McMillan K., Tenney D., Meert J-P., Bradley P. (2014). Fitness in soccer: The science and practical application. Leuven: Moveo Ergo Sum.

8. Bangsbo J. (1994). The physiology of soccer with special reference to intense intermittent exercise. Acta Physiologica Scandinavica 619, 1-155.

9. Gissis I., Papadopoulos C., Kalapotharakos V.I., Sotiropoulos A., Komsis G., Manolopoulos E. (2006). Strength and speed characteristics of elite, subelite, and recreational young soccer players. Research in Sports Medicine 14, 205-214.

10. Nowacki P.E., Cai D.Y., Buhl C. et al. (1988). Biological performance of German soccer players (professionals and juniors) tested by special ergometry and treadmill methods. In T. Reilly, A. Lees, K. Davids et al. (eds), Science and football (pp. 145-157). London: E \& FN Spon.

11. Lesinski M., Muehlbauer T., Granacher U. (2016). Concurrent validity of the Gyko inertial sensor system for the assessment of vertical jump height in female sub-elite youth soccer players. BMC Sports Science, Medicine and Rehabilitation 8, 35. 
12. Markovic G. (2007). Does plyometric training improve vertical jump height? A meta-analytical review. British Journal of Sports Medicine 41(6), 349-355.

13. Dias J.A., Dal Pupo J., Reis D.C., Borges L., Santos S.G., Moro A.R. et al. (2011). Validity of two methods for estimation of vertical jump height. Journal of Strength and Conditioning Research 25(7), 2034-9. DOI: 10.1519/JSC.0b013e318le73f6e.

14. Stone M.H., Stone M.E., Sands W.A. (2007). Principles of resistance training. Champaign: Human Kinetics.

15. Hart S., Drevets K., Alford M., Hunt B.E. (2013). A methodcomparison study regarding the validity and reliability of the Lactate Plus analyzer. BMJ Open 3(2), e001899. DOI: 10.1136/bmjopen-2012-001899.

16. Tanner R.K., Fuller K.L., Ross M.L. (2010). Evaluation of three portable blood lactate analysers: Lactate Pro, Lactate Scout and Lactate Plus. European Journal of Applied Physiology 109(3), 551-9. DOI: 10.1007/s00421-010-1379-9.

17. Schönfelder M., Hinterseher G., Peter P., Spitzenpfeil P. (2011). Scientific comparison of different online heart rate monitoring systems. International Journal of Telemedicine and Applications 5, 631848. DOI: 10.1155/2011/631848.

18. Berthon P., Fellmann N., Bedu M., Beaune B., Dabonneville M., Coudert J. et al. (1997). A 5-min running field test as a measurement of maximal aerobic velocity. European Journal of Applied Physiology 75, 233-238.

19. Verheijen R. (2014). The original guide to football periodization. Part 1. Naarden, Netherlands: World Football Academy.

20. Jurkowski B., Wysocki C. (2011). Analysis of preparation period in football based on the example of the first-league teams Górnik Łęczna and Zagłębie Lubin. Roczniki Naukowe Wyższej Szkoły Wychowania Fizycznego i Turystyki w Biatymstoku 7, 52-68. [in Polish]

21. Sledziewski D. (2002). Individualisation in sport training process. Rocznik Naukowy AWFiS 12, 101-108. [in Polish]

22. Śliwowski R., Andrzejewski M., Wieczorek A., BarinowWojewódzki A., Jadczak Ł., Adrian J. et al. (2013). Changes in the anaerobic threshold in an annual cycle of sport training of young soccer players. Biology of Sport 30, 137-143.

23. McMillan K., Helgerud J., Grant S.J., Newell J., Wilson R., Macdonald R. et al. (2005). Lactate threshold responses to a season of professional British youth soccer. British Journal of Sports Medicine 39, 432-436.

24. Silva A.S.R., Santhaigo V., Papoti M., Gobato C.A. (2007). Hematological parameter and anaerobic threshold in Brazilian soccer players throughout a training program. International Journal of Laboratory Hematology 30, 158-166.

25. Yildirim A., Emre A.K., Korkusuz F., Cicec S. (2008). Physiological profiles of soccer players with respect to playing positions. In T. Reilly, F. Korkusuz (eds), Science and Football VI (pp. 370-373). New York: Routledge.

26. Ferrari Bravo D., Impellizzeri F.M., Rampinini E., Castagna C., Bishop D., Wisloff U. (2008). Sprints vs. interval training in football. International Journal of Sports Medicine 29(8), 668-674.

27. Impellizzeri F., Marcora S., Castagna C., Reilly T., Sassi T., Iaia F.M. et al. (2006). Physiological and performance effects of generic versus specific aerobic training in soccer players. International Journal of Sports Medicine 27(6), 483-492.
28. Valquer W., Barros T.L., Sant'anna M. (1998). High intensity motion pattern analyses of Brazilian elite soccer players. In F. Tavares (ed.), IV World Congress of Notational Analysis of Sport (p. 80). Porto: FCDEF-UP.

29. Murphy A.J., Lockie R.G., Coutis A.J. (2003). Kinematic determinants of early acceleration in field sport athletes. Journal of Sports Science and Medicine 2, 144-150.

30. Boone J., Vaeyes R., Steyaert A., Vanden Bossche L., Bourgois J. (2012). Physical fitness of elite Belgian soccer players by player position. Journal of Strength and Conditioning Research 26(8), 2051-2057.

31. Yanci J., Los Arcos A., Grande I., Casajus J.A. (2016). Change of direction ability test differentiates higher level and lower level soccer referees. Biology of Sport 33(2), 173-177.

32. Styles W.J., Matthews M.J., Comfort P. (2016). Effects of strength training on squat and sprint performance in soccer players. Journal of Strength and Conditioning Research 30(6), 1534-9. DOI: 10.1519/JSC.0000000000001243.

33. Wong D.P., Chaouachi A., Chamari K., Dellal A., Wisloff U. (2009). Effect of preseason concurrent muscular strength and high-intensity interval training in professional soccer players. Journal of Strength and Conditioning 24(3), 653-660.

34. Tous-Fajardo J., Gonzalo-Skok O., Arjol-Serrano J.L., Tesch P. (2016). Enhancing change-of-direction speed in soccer players by functional inertial eccentric overload and vibration training. International Journal of Sports Physiology and Performance 11, 66-73.

35. Cotte T., Chatard J-C. (2011). Isokinetic strength and sprint times in English Premier League football players. Biology of Sport 28, 89-94.

36. Commetti G., Maffiuletti N., Pousson M., Chatard J-C., Maffulli N. (2001). Isokinetic strength and anaerobic power of elite, subelite and amateur French soccer players. International Journal of Sports Medicine 22(1), 45-51.

37. Cronin J.B., Hansen K.T. (2005). Strength and power predictors of sports speed. Journal of Strength and Conditioning Research 19, 349-357.

38. Wong D.P., Chmari. K., Wisloff U. (2010). Effects of 12-week on-field combined strength and power training on physical performance among U-14 young soccer players. Journal of Strength and Conditioning Research 24(3), 644-652.

39. Loturco I., Pereira L.A., Kobal R., Maldonado T., Piazzi A.F., Bottino A. et al. (2016). Improving sprint performance in soccer: Effectiveness of jump squat and Olympic push press exercises. PLoS One 11(4), e0153958. DOI: 10.1371/journal. pone. 0153958.

40. Lehance C., Binet J., Bury T., Croisier J.L. (2009). Muscular strength, functional performance and injury risk in professional and junior elite soccer players. Scandinavian Journal of Medicine E Science in Sports 19(2), 243-251.

41. Requena B., Gonzalez Badillo J.J., Saez de Villareal E., Ereline J., Garcia I., Gapayeva H. (2009). Functional performance, maximal strength, and power characteristics in isometric and dynamic actions of lower extremities in soccer players. Journal of Strength and Conditioning Research 23(5), 1391-1401.

Submitted: May 18, 2017

Accepted: September 4, 2017 